\title{
Islamic Calendar Anomalies: Evidence from Pakistani Firm-Level Data
}

\author{
Anwar Halari ${ }^{\mathrm{a}, *}$, Nongnuch Tantisantiwong ${ }^{\mathrm{b}}$, David. M. Power ${ }^{\mathrm{c}}$, Christine Helliar $^{\mathrm{d}}$ \\ ${ }^{a}$ School of Business, University of Buckingham, Buckingham, MK18 1EG, UK \\ ${ }^{b}$ Southampton Business School, University of Southampton, Southampton, SO17 1BJ, UK \\ 'School of Business, University of Dundee, Dundee, DD1 4HN, UK \\ ${ }^{\mathrm{d} S}$ School of Commerce, University of South Australia, Adelaide, SA 5001, Australia
}

This version: January 2015

\begin{abstract}
Most prior research has tested for monthly regularities based on the Gregorian calendar; by contrast, little attention has been given to other calendars based on different religions or cultures. This paper examines Islamic monthly anomalies in a stock market located within a Muslim country - Pakistan. The study employs data for 106 companies listed on the Karachi Stock Exchange (KSE) over the period from 1995 to 2011 and an asymmetric generalized autoregressive conditional heteroscedasticity model to examine whether the mean value and volatility of share returns in the KSE vary with Islamic months. The results from the model offer very little statistical evidence of a monthly seasonal anomaly in average returns, but there is evidence of monthly patterns in the volatility of returns for KSE equities. This finding suggests that investors can formulate an investment strategy and choose a trading time in order to outperform on a risk-adjusted basis.
\end{abstract}

JEL classification: C58; G02; G14; G17

Keywords: Islamic calendar anomalies; stock returns; conditional volatility; behavioural finance, September 11 attacks

* Corresponding author, Tel: +44 1280820296

E-mail addresses: Anwar.Halari@buckingham.ac.uk; N.Tantisantiwong@soton.ac.uk;

D.M.Power@dundee.ac.uk; Christine.Helliar@unisa.edu.au 


\section{Introduction}

Early findings of the Efficient Market Hypothesis (EMH) were supportive of the hypothesis, but more recent evidence has thrown up several irregularities known as market 'anomalies' which cast doubt on the theory's validity (Jensen, 1978). These anomalies can appear at different times of the day (Harris, 1986; Ariel, 1987), on different days of the week (Jaffe and Westerfield, 1985; Brooks and Kim, 1997) and in different months of the year (Gultekin and Gultekin, 1983; Gamble, 1993). Monthly calendar irregularities have been shown to be a persistent anomaly in capital markets throughout the world; the returns in some months (especially January) are consistently higher than in others. The substantive literature relating to calendar anomalies appears to have initially concentrated on the share returns of developed markets such as the UK and the US. However, a relatively small number of investigations have begun to study the existence of monthly calendar anomalies in the stock markets of Muslim countries such as Pakistan (Ali and Akbar, 2009; Zafar et al., 2010; Rafique and Shah, 2012). Calendar anomalies may be explained by the tax system of a country (Dyl, 1977; Roll, 1983; Dbouk et al., 2013), the institutional structures within a market (Hepsen, 2012), the trading mechanisms that may be in place (Fama and Blume, 1996) or cultural factors (Chan et al., 1996; Bley and Saad, 2010); hence differences would be expected in the monthly performance of equities from one country to another. Thus, an analysis for a country such as Pakistan may offer interesting insights because monthly anomalies may be different from those in developed nations. Exploring Islamic monthly calendar anomalies in the KSE are appropriate as Muslims account for over 97 percent of the population in Pakistan; the results may have important implications for our understanding of the dynamics of pricing efficiency in countries which follow Islamic laws and customs.

The Islamic calendar year is approximately 11 days shorter than its Gregorian counterpart; this means that while Islamic months (and Muslim holy days) fall on the same 
date in the Islamic calendar, they actually vary by a few days each year on the Gregorian calendar (Halari, 2015). With this variability in the dates of Islamic calendar months relative to their Gregorian counterparts, any seasonality uncovered in this paper is likely to be caused by factors other than those examined in the case of developed capital markets.

As with its Gregorian counterpart, the Islamic calendar has twelve months but only a total of either 354 or 355 days in a year. An Islamic calendar month consists of either 29 or 30 days (based on the lunar cycle) unlike some of the Gregorian calendar months that go up to 31 days. The beginnings and endings of an Islamic calendar month are determined by the sighting of the crescent moon - known as 'Hilal'" in Arabic. The 12 Islamic months are: Muharram, Safar, Rabiul Awwal, Rabiul Thani, Jamatul Awwal, Jamatul Thani, Rajab, Shaban, Ramadan, Shawwal, Zil Qa'ad and Zil Hajj.

From an investment perspective, different Islamic months may be important because of the emotions that they evoke in individual religious observers as well as in the Muslim community of the country as a whole. Major historical Islamic events that took place during specific months can explain the emotions of Muslims at various times of the year. For example, the 9th month of the Islamic calendar, the month of Ramadan, is dominated by positive emotions and a joyous mood as Muslims exercise their faith in anticipation of reaping the blessings of the month and the forgiveness of their past sins (Al-Ississ, 2010). Ramadan is associated with increased consumer spending, similar to the shopping period during the run-up to Christmas in Western countries. Generally, in Muslim countries, business activity in the month of Ramadan is different from that in other months.

\footnotetext{
${ }^{1}$ The word means crescent-moon in Arabic. Muslims look for the 'hilal' when determining the beginning and end of Islamic months. After the $29^{\text {th }}$ sunset of the current month, the crescent of the next month is observed. Since this new moon (crescent) sets a while after the sunset, it requires careful observation. If the sky is somehow blocked by dust, smog or cloud, observation may be hard or even impossible. If the crescent cannot be observed, the current month is counted as 30 days. In such a situation, there is no need to observe the crescent the next day. The second month would be due that day by sunset since no lunar month lasts longer than 30 days. The exact day of the beginning of each Islamic month is not generally known until the night before, when the moon is actually sighted and confirmed.
} 
Furthermore, during the month of Ramadan, economic activity within Islamic countries such as Pakistan slows down as people devote more time to the performance of religious rituals. The financial markets reduce their trading hours while restaurants and shops are closed during the day. The trading times at the Karachi Stock Exchange (KSE) are reduced by more than an hour during Ramadan (Husain, 1998; Bialkowski et al., 2012). Normally, trading hours are 9:30am-3:30pm from Monday to Thursday with a pre-open session of 15 minutes. There are two sessions on Friday with a prayer break in between. The first session runs from 9:15am to $12: 00 \mathrm{pm}$ while the second session operates from 2:30am to 4:30pm. During Ramadan, trading hours of the KSE are 9:15am-2:00pm from Monday to Thursday and 09:15am-12:30pm on Friday with a pre-open session of 15 minutes.

Apart from Ramadan, important Islamic events also occur in the other 11 months too. For example, at the start of Shawwal, the month following Ramadan, Muslims celebrate the festival of Eid-ul-Fitr, which marks the end of fasting. The behaviour of the people returns to normal after Eid-ul-Fitr. In Zil-Hajj which is the last month of the Islamic year, a large number of Muslims perform the annual pilgrimage to Mecca, animals such as cows, goats, and camels are slaughtered in memory of the sacrifice performed by Prophet Abraham and consumption increases while savings fall (Mustafa, 2008). Such changes in consumer behaviour during the different Islamic months may affect the returns of KSE listed securities and explain any Islamic calendar anomalies that may be present.

Most Pakistani studies about calendar anomalies focus on the day-of-the-week effect (Nishat and Mustafa, 2002; Ullah et al., 2010; Hussain et al., 2011) while only a handful of studies look at monthly seasonality for the KSE. Yet, monthly seasonality is arguably a more realistic strategy for investors to follow since the transaction costs of attempting to exploit the former are very high - especially in a country where the derivatives market is relatively underdeveloped (Arif, 2007). Most Pakistani studies that have investigated monthly calendar 
anomalies have focused on the Gregorian calendar and assumed the risk to be unchanged over time. Two exceptions to this generalization are the studies by Husain (1998) and Mustafa (2008) which examined share returns from the KSE for any anomalous behaviour around Islamic calendar months while modelling volatility in equity returns. However, Husain (1998) only examined equity prices for a limited time span, while Mustafa (2008) focused on index data and only investigated returns for six of the Islamic months. ${ }^{2}$

The current research extends the findings of earlier work by testing data for a large number of listed firms in an Islamic country and examining a long time period for the Islamic calendar effect on both stock returns and volatility using an asymmetric Generalized Autoregressive Conditional Heteroscedasticity (GARCH) model; more specifically, a Threshold GARCH (TGARCH) model. The impact on the volatility of KSE share returns of the terrorist attack on the Twin Towers in New York on September 11, 2001 (9/11), which previous studies have overlooked, is also investigated. To the best of our knowledge, this paper is one of the first to examine calendar effects on share returns and volatility across all 12 Islamic months for the KSE using an asymmetric GARCH approach. Ultimately, the current study adds to our knowledge about financial markets in non-developed countries with sizeable Muslim populations.

The remainder of this paper is organized as follows. Background information about the KSE is discussed in Section 2 while Section 3 provides a review of the relevant literature. Section 4 describes the data and reports on the descriptive statistics. The methodology is outlined in Section 5 while the results are presented in Section 6. Finally, Section 7 concludes.

\footnotetext{
${ }^{2}$ The Islamic months studied were Muharram, Shaban, Ramadan, Shawwal, Zil Qa'ad and Zil Hajj.
} 


\section{An Overview of the Karachi Stock Exchange}

The KSE is the main stock exchange of Pakistan; it is the largest and the most active stock exchange in the country with over 560 Pakistani as well as overseas companies listed; its capitalization amounts to 40 percent of the national GDP with a value of Rs. 5336 billion at the end of 2013. ${ }^{3}$ It is the most active and liquid exchange in Pakistan with over 92 percent of the country's market capitalization belonging to firms listed in the KSE. Therefore, the KSE was chosen as the primary source of data.

The KSE has grown in size and importance since its establishment on September 18, 1947. This growth was especially pronounced for share trading in the 1990s as barriers to foreign investments were removed and measures to deregulate the economy were adopted (Mirza, 1993). The increase in trading has been associated with a rise in volatility which grew throughout the 1990s (Farid and Ashraf, 1995; Ahmed and Rosser, 1995; Iqbal, 2012). Indeed, Farid and Ashraf (1995) documented that during the first half of 1994 a majority of investors entered the market when it was rising, and abandoned it when it started to fall. In other words, many investors seemed to simply track the market increasing the volatility of share prices. This impact of "naive" investors may have been exacerbated by a dearth of sophisticated investors within the country as no sizeable analyst community exists in Pakistan while large investment funds are not common. Further, volatility in the KSE market has clustered since 2003 (Kanasro et al., 2009; Nawazish and Sara, 2012). Thus, the conditional variance should be taken into account when assessing a KSE security's performance.

Many studies also document a significant shift in the volatility of share returns in Pakistan after the terrorist attacks of 9/11 (Hameed and Ashraf, 2006; Ahmed and Farooq,

\footnotetext{
${ }^{3}$ The data has been collected from the Economic Surveys produced by Pakistan's Ministry of Finance in 2014. These indicate that it is a small market with high turnover which is a common feature in emerging stock markets around the world. The reasons for the shallowness of the market and high levels of turnover in emerging markets are poor information, insider trading, liquidity, and market manipulation. In developed markets, the market capitalization ratio to GDP is large and turnover is small. The Pakistani stock market stands in contrast to developed markets like the US in which the market capitalization to GDP ratio is 92 percent and turnover is 65 percent (Mustafa and Nishat, 2007).
} 
2008; Nguyen and Enomoto, 2009; Suleman, 2012). For example, Ahmed and Farooq (2008) found that the conditional variance, risk premium and the asymmetric response of the conditional variance to past shocks in KSE returns changed significantly from their pre-9/11 levels during the post- 9/11 period. They argued that

"Some of the benefits, such as surge in remittances via formal channels, increase in export quotas for textiles to the EU and US, and rescheduling of country's debt, not only helped in improving the firm performances but also enhanced the liquidity and investor participation in the KSE" (p. 71).

The surge in capital and higher liquidity after 9/11 led the Security and Exchange Commission of Pakistan (SECP) to reform the market e.g. the introduction of a $\mathrm{T}+3$ settlement period and the imposition of circuit breakers (Hameed and Ashraf, 2006). It is evident from Figure 1 that while the mean value of stock returns was not greatly affected by these reforms after 9/11, their volatility was relatively lower after the changes were introduced. An analysis of Figure 1 indicates that while the differences in the mean values of share returns (pre-9/11 minus post-9/11) is virtually zero, a different story emerges for the volatility. The differences in volatility after $9 / 11$ are clearly visible with majority of the firms documenting negative values for the change in standard deviation suggesting that share price changes pre 9/11 were far more erratic and volatile compared to their post 9/11 values. This observation is consistent with previous studies that have documented a significant shift in the volatility of share returns in Pakistan after the terrorist attacks of 9/11 (Hameed and Ashraf, 2006; Ahmed and Farooq, 2008; Nguyen and Enomoto, 2009; Suleman, 2012). ${ }^{4}$ The present investigation examines the volatility of share returns across the 12 Islamic months both pre and post $9 / 11$.

\section{[Insert Figure 1 and Figure 2 about here]}

\footnotetext{
${ }^{4}$ This feature can also be noted in Figure 2 for individual firms. Due to the large amount of sample firms, only four firms are shown in Figures 2; however, similar observations were documented for a majority of firms in the sample.
} 


\section{Literature Review}

Very little literature exists on predictability in share returns at different times of the Islamic calendar compared to its Gregorian counterpart. One reason why a seasonal pattern may exist in share returns at different times of the Islamic calendar is that economic and financial activities in Muslim countries fluctuate according to the Islamic month of the year. Researchers as far back as Weber (1930) documented that activities associated with religious beliefs may have an impact on the economic activities of a country. More recently, Canepa and Ibnrubbian (2014) reported that religious believes had important bearing on portfolio choices of investors in Saudi Arabia.

One of the Islamic months where seasonal patterns have been explored when testing for predictability is Ramadan. Oguzsoy and Guven (2004) examined data for the Istanbul stock market over the period 1988 and 1999 using the Istanbul stock exchange (ISE) 100 stock index and the ISE 30 stock index, and confirmed that a Ramadan effect was prevalent with a significant increase in the average returns during that period. Unlike Oguzsoy and Guven (2004), Seyyed et al. (2005) used a symmetric GARCH specification on the returns of the Saudi Arabian stock market and found that while Ramadan did not have an effect on returns, there was a significant decline in volatility.

Recently, Al-Ississ (2010) examined the impact of religious events on stock market indices and trading volumes for Muslim holy days during Ramadan and Ashoura ${ }^{5}$ in 17 financial markets of "Islamic" countries over a 20 year period from 1988 to 2008. His analysis documented that Ramadan had a positive impact on daily returns in the financial markets of all Muslim countries investigated while Ashoura was associated with a negative effect. Al Ississ (2010) also highlighted that religious events affected the trading volumes of the financial markets studied; volumes declined by approximately 0.33 percent on average for

\footnotetext{
${ }^{5}$ Ashoura is the $10^{\text {th }}$ day of Muharram in the Islamic calendar and marks the climax of the remembrance of the battle of Karbala.
} 
Ramadan. Like Al Ississ (2010), Al-Hajieh et al. (2011) documented that mean returns of Egypt, Jordan, Kuwait and Turkey in Ramadan were higher than the yearly mean returns (excluding Ramadan) during the period from 1992 to 2007.

Bialkowski et al. (2012) also studied seasonal anomalies associated with 14 Islamic stock market indices over the period from 1989 to 2007 while Almudhaf (2012) analysed the stock market indices of 12 predominantly Muslim countries over 1996 to 2007. Using linear models, both studies reported that during the month of Ramadan, the mean annualized return of the Pakistani stock market was, on average, greater than the mean return over the rest of the Islamic year and there was a significant decrease in volatility during Ramadan. Most recently, Al-Khazali (2014) revisited the Ramadan effect in the stock returns of 15 Muslim countries (including Pakistan) using stochastic dominance (SD) approach over the period from 1989 to 2012 . The results indicated that stock markets did not outperform in Ramadan from a wealth perspective for the countries investigated; however, the author reported that risk-averse investors would prefer investing during the month of Ramadan relative to the other months of the Islamic calendar.

Husain (1998) focused particularly on Pakistan using data from 1989 to 1993 analysing daily share prices for 36 individual shares, eight sector indices and the general market index using a symmetric GARCH model. He found that volatility declined in Ramadan, but this reduction in the variability of stock returns was not significant. Mustafa (2008) explained that Husain (1998) only studied the month of Ramadan for a relatively small time period so he used the KSE-100 index over the period 1998 to 2004 to analyse not only the month of Ramadan but also five other Islamic months. Mustafa (2008) found no Ramadan effect, but that there were significantly positive returns in the months which followed Ramadan (Shawwal and Zil Qa'ad). Similar to the findings of the earlier studies, he noted that the risk was lower in the month of Ramadan. 
These findings suggest that there are patterns in the returns of Islamic financial markets. The current paper adds to this sparse literature by examining all 12 Islamic months for the Pakistani stock market using the firm-level data. To the best of our knowledge, this is one of the few studies that investigates all 12 Islamic months for calendar anomalies on the mean and volatility of share returns using an asymmetric GARCH model. Unlike previous studies in this area, this paper also considers the effect of good and bad news (the leverage effect) on share prices as well as the change in volatility after $9 / 11$.

\section{Data and Preliminary Analysis}

This paper examines daily share returns for 106 companies listed on the KSE over the 17 year period from January 1, 1995 to December 31, 2011. The start date was chosen in order to maximize the number of companies included in the data set whilst having a long enough time frame to investigate monthly calendar anomalies. This study employs individual companies' data instead of the KSE index employed in most previous studies (Mustafa, 2008; Zafar et al., 2010; Ali and Akbar, 2009) to provide a more realistic view of whether abnormal returns can be exploited by investors.

A sample of 106 companies were analysed for the current investigation. This sample of companies covers a broad spectrum of the KSE market. This sample is applied to ensure that the results are not specific to a particular sector or size of company. ${ }^{6}$ Since stock dividends, stock splits and share issues were relatively common for the KSE equities over the

\footnotetext{
${ }^{6}$ There were a total of 638 companies listed on the KSE at the end of December 2011; out of these, only 564 had data available on Datastream. From this sample of 564 firms, only 176 companies had a start date before January 1995. Of those 176 companies, 39 firms did not have adjusted prices and 31 companies were found to be inactively traded. Inactive shares are shares listed on the stock exchange that are not traded frequently. Trades were not apparent for certain firms for periods of over nine months at a time. For the purpose of this study, a cut-off point of 33 percent was employed, so the share was included in the sample if 33 percent or more of the returns for a share were different from zero.
} 
17-year period of this research, it was decided to use adjusted prices. ${ }^{7}$ Details about the sample companies are provided in Appendix 1.

Returns for this sample were computed as the first differences of the natural logarithm of prices:

$\mathrm{R}_{\mathrm{it}}=\operatorname{Ln}\left(\mathrm{P}_{\mathrm{it}}\right)-\operatorname{Ln}\left(\mathrm{P}_{\mathrm{it}-1}\right)$

Where $\mathrm{Ln}$ is the natural logarithm; $\mathrm{R}_{\mathrm{it}}$ is the return on share $\mathrm{i}$ for day $\mathrm{t}$; $\mathrm{P}_{\mathrm{it}}$ and $\mathrm{P}_{\mathrm{it}-1}$ are the prices of firm i for day $t$ and $t-1$, respectively. A total of 4435 Gregorian calendar dates for the 17 year period from 1995 to 2011 were converted to Islamic dates in order to conduct this investigation; after excluding the non-trading days, the total number of observations was reduced to 4067. Two newspaper archives and a Gregorian-Islamic date convertor were used when undertaking this task. ${ }^{8}$

\section{[Insert Table 1 about here]}

Table 1 shows the descriptive statistics for the average daily returns across the 106 firms according to the Islamic calendar. ${ }^{9}$ The descriptive statistics summarize the mean (MEAN), the standard deviation (SD), the minimum (MIN) and the maximum (MAX) return. A measure of skewness (SKEW) and kurtosis (KURT) for the whole 17-year period as well

\footnotetext{
${ }^{7}$ An 'adjusted price' is the price of a company's share after taking into account any stock dividends, stock splits or share issues

8 The Gregorian-Islamic date convertor used was from the website called Islamic Finder (http://www.islamicfinder.org/dateConversion.php). These results were matched with the results of newspaper archives and any discrepancies investigated until a full Islamic calendar was determined. Islamic calendars issued in Pakistan could not be used as these calendars are estimated for the coming years; they are forward looking when issued and may turn out to be incorrect based on the lunar cycle. The actual dates may have been different from these predictions based on actual sightings of the moon. The archives of two newspapers (Dawn and the Daily Express) were searched so as to mitigate any errors which might be present and to cross check the results of one publication with another. Dawn is the oldest and most widely read English newspaper in Pakistan while Daily Express is one of Pakistan's most widely circulated Urdu newspapers.

${ }^{9}$ Descriptive statistics for individual companies are available upon request.
} 
as the Jarque-Bera normality test statistics (JB) are also provided. A visual examination of Table 1 suggests that over the 17-year period investors earned the highest mean return in the month of Ramadan; the average return for this month is 0.175 percent while the average return for the whole year is 0.015 percent. This result is consistent with the findings of AlIssiss (2010) and Al-Hajieh et al. (2011). In line with the findings of Mustafa (2008), the months of Shawwal and Zil Qa'ad were found to have the second and third highest mean returns. The lowest mean return was for the two months preceding Ramadan (Rajab at -0.058 percent and Shaban at -0.053 percent).

According to Table 1, the highest return volatility occurred in Safar whereas the lowest return volatility occurred in Ramadan. With the highest mean returns and lowest return volatility, Ramadan seems to be the best month to invest in KSE. Furthermore, the volatile nature of equity prices for the KSE is confirmed by the range between minimum and maximum values. Across all the Islamic calendar months, the minimum daily average return across 106 firms ranged between -3.1 and -6.0 percent whereas the maximum daily average returns varied from 2.7 to 6.7 percent. An in-depth examination of the stock returns indicated that the average daily return across the 106 firms peaked at 6.7 percent in the month of Rabiul Awwal during 2002. The period with the lowest return at -6.0 percent was also in Rabiul Awwal during 2002. This month coincided with tension between India and Pakistan over Kashmir; more than a million troops were massed along the two countries' border. It was feared that this conflict might cause a war between the two nuclear-armed countries and this political shock may have affected trading in the Pakistani stock market. At the firm level, we find that the lowest daily return across the sample occurred in Rajab in 1997 (Dewan Automotive Engineering with a daily return of -98 percent) and the highest daily return across the sample occurred in Zil Qa'ad in 2011 (Unicap Modarba Ltd., a financial 
institution, with a daily return of 88 percent). Moreover, for most Islamic months the firms with the maximum or minimum daily return tended to be in the financial sector.

Results of the Jarque-Bera normality test suggest that the daily average returns across the 106 firms are not normally distributed. The fifth and sixth columns of Table 1 suggest that returns were negatively skewed in 8 of the 12 Islamic months; out of the 106 firms, 97 had negative skewness statistics that were significant at the 5 percent level. ${ }^{10}$ In addition, the kurtosis statistics were all higher than the critical value of 3 suggesting that the return distributions for all 12 Islamic months were characterized by fat-tails; there were more observations in the tail than one would normally expect. This suggests that a GARCH model may be appropriate for analysing KSE returns, as detailed in the next section ${ }^{11}$.

\section{Methodology}

The share returns were tested for the presence of monthly calendar anomalies in KSE equities using the TGARCH $(1,1)$ model under the assumption of time-varying return volatility. ${ }^{12}$ This model allows for time-varying volatility and takes account of any leverage effect (Black, 1976) which may be present where the impact of good news may be different from the effect of bad news on the variance of returns.

To examine any monthly seasonality in share returns and volatility, the following TGARCH $(1,1)$ model was estimated:

\footnotetext{
${ }^{10}$ Values of skewness were deemed significant if they were more than twice their standard errors. In the current analysis, the standard error values documented for the skewness statistics varied from -4.97 for Fazal Textile Mills to 1.47 for Pakistan National Shipping.

11 Before deciding to use a GARCH model, the Engle (1982) test of Autoregressive Conditional Heteroscedasticity $(\mathrm{ARCH})$ effects was conducted to ascertain whether a GARCH model is appropriate for the data. The test statistic was distributed as $\chi^{2}$ under the null hypothesis of no ARCH effects. The results at the lags of 6,12 and 20 confirmed that an ARCH effect was present in the data for all firms. Hence, the use of GARCH-type model was deemed appropriate for this research.

12 A pilot study on a random selection of 30 sample firms was conducted to select an appropriate GARCH model. The Ljung - Box test result indicated that compared with GARCH(1,1), EGARCH(1,1) and TGARCH$\mathrm{M}(1,1)$ models, the TGARCH $(1,1)$ model best fitted the data for this investigation. An analysis for all the sample firms confirmed that the TGARCH model does not have serial correlations in the standardized and the squared standardized residuals indicating the appropriateness of TGARCH specification for data under investigation.
} 


$$
\begin{aligned}
& R_{j t}=\mu_{j}+\sum_{i=1}^{11} \lambda_{i j} D_{i t}+\varepsilon_{j t} \\
& h_{j t}=\theta_{j}+\sum_{i=1}^{11} \delta_{i j} D_{i t}+\varphi_{j} D_{c t}+\alpha_{j} \varepsilon_{j t-1}^{2}+\beta_{j} h_{j t-1}+\gamma_{j} \varepsilon_{j t-1}^{2} \mathrm{I}_{j t-1}
\end{aligned}
$$

Equation (2) is the mean equation where $R_{j t}$ is the stock return at time $\mathrm{t}$ for each firm examined. $\varepsilon_{\mathrm{jt}}$ is the random error term where $\varepsilon_{\mathrm{jt}} \sim N\left(0, h_{t}\right)$. Equation (3) is the variance equation that captures the time-varying volatility in the return series where $h_{j t}$ is the conditional variance since it is a one-period ahead estimate for the variance calculated on the basis of past information. $\varepsilon_{j t-1}^{2}$ is the unexpected return during the previous period, known as the 'ARCH term'. $h_{j t-1}$ is the conditional variance in the previous period, also referred to as the 'GARCH term'. $\mathrm{I}_{j t-1}$ is a dummy variable for bad news or negative shocks to share returns i.e. $\mathrm{I}_{j t-1}=1$ if $\varepsilon_{j t-1}<0$ (bad news) and 0 otherwise. $\gamma_{j}$ is the asymmetric leverage effect. A positive value for $\gamma_{j}$ implies that negative shocks have a larger impact on volatility than positive shocks; whereas, a negative value for $\gamma_{j}$ indicates that the positive shocks have a larger impact on volatility than their negative counterparts. The news impact is symmetric if $\gamma_{j}=0$

The model is specified according to the Islamic calendar; eleven monthly dummy variables in the mean and variance equations of the share returns are included to proxy for Muharram through Zil Qa'ad with intercept terms ( $\mu_{j}$ in equation (2) and $\theta_{j}$ in equation(3)) representing the $12^{\text {th }}$ month (Zil Hajj). ${ }^{13}$ In other words, Zil Hajj becomes the reference month against which all the other months are compared. In both equations, $D_{i t}$ is a set of 11

\footnotetext{
${ }^{13}$ This is consistent with the study by Beller and Nofsinger (1998) using Gregorian calendar that had 11 dummy variables and December as the intercept (constant) term to avoid the perfect multicollinearity problem.
} 
dummy variables for each of the 11 months from Muharram to Zil Qa'ad where $\mathrm{D}_{1 \mathrm{t}}=1$ for all Muharram observations and 0 otherwise, $\mathrm{D}_{2 \mathrm{t}}=1$ for all Safar observations and 0 otherwise and so on.

As can be seen from Figure 1 and 2, a structural break was identified in the time series after $9 / 11$. A $9 / 11$ crisis dummy " $D_{c t}$ " is therefore introduced into the variance equation, but not the mean equation. $D_{c t}$ has a value of zero for the period before September 11, 2001 and the value of 1 for all the observations after that date. Equation (1) and equation (2) are estimated simultaneously by using a Quasi Maximum Likelihood approach (QML) (see Bollerslev and Wooldridge, 1992). The maximum likelihood is performed using the Berndt, Hall, Hall and Hausman (BHHH) algorithm (Berndt et al., 1974). The results from this investigation are discussed in the next section.

\section{Results}

The distributions of coefficients of the TGARCH model across 106 firms are presented in Table 2. ${ }^{14}$ The table is divided into three panels. The first panel reports month effects on mean returns while the second panel documents month effects on volatility. The final panel presents the distributions of coefficients for the ARCH, GARCH, leverage effect and the 9/11 dummy. Each panel has nine columns; the first simply highlights the name of the variables for which the coefficient's statistics are being provided. The second column highlights the average coefficients for each variable across all 106 companies. The next two columns report the percentage of these coefficients that were (i) significant and (ii) negative. The fifth and sixth columns document the minimum and maximum values for each coefficient respectively while the seventh column reports the standard deviation for each

\footnotetext{
${ }^{14}$ Results for each individual firm are available upon request.
} 
coefficient around its mean. Finally, the last two columns describe the skewness and kurtosis of each coefficient's distribution.

\section{[Insert Table 2 about here]}

\subsection{Islamic calendar anomalies in mean returns}

A notable feature of the results in Table 2 is the positive Ramadan effect. This is consistent with studies that have documented evidence of a Ramadan effect in various Islamic countries (Al-Ississ, 2010; Al-Hajieh et al., 2010; Almudhaf, 2012; Bailkowski et al., 2012). It is clear from the results of the mean equation in Table 2 that investors earn the highest mean return (relative to Zil Hajj) during the month of Ramadan; the average value of the coefficient for this month is 0.1250 , nearly 40 percent higher than that documented for the month with the next highest coefficient (Zil Qa'ad). Not surprisingly, Ramadan also reported the least negative coefficient; only 24.53 percent of the sample firms had a negative Ramadan coefficient. However, after allowing the volatility to vary, the Ramadan effect is no longer as strong as other studies documented. Only a relatively small percentage of firms (5.66 percent) had a significant coefficient for this month. These firms are General Tyre, Hinopak Motors, MCB Bank, Pak Suzuki Motor, Siemens Engineering, and Sui Southern Gas. Apart from MCB Bank, all other firms were small relatively to the size of the KSE. The insignificance of coefficient for the month of Ramadan for many stocks suggests that the results in prior studies which did not take the return volatility into account may be due to misspecification or the implicit effect of time-varying market volatility. Table 2 shows that the distribution of the Ramadan effect across 106 firms is negatively skewed. However, a more in-depth analysis of the results focusing only on firms with significant coefficients reveals that none of the firms of the sample has a significantly negative Ramadan effect. 
Furthermore, the results suggest that the two months following Ramadan (Shawwal and Zil Qa'ad) and Rabiul Awwal also reported positive coefficients; Zil Qa'ad had the second highest coefficient at 0.0899 followed by Shawwal at 0.0461 although these coefficients were only significant for 1.89 and 4.72 percent of the sample firms respectively. This finding is consistent with the results of Mustafa (2008) who documented an 'after Ramadan' effect on the KSE-100 index. However, in the current investigation, this 'after Ramadan' effect is not significant for most firms.

Unlike prior studies, the results of both the descriptive statistics and the TGARCH estimations reveal that Rajab has the lowest returns compared to all the other months of the Islamic calendar. Moreover, all of the significant coefficients for Rajab are negative. These results imply that investors may be exposed to loss if they invest in certain firms during the month of Rajab. On the other hand, investors may be able to make profit from a strategy of investing in certain firms during the month of Ramadan.

\subsection{Islamic calendar anomalies in return volatility}

The results of the variance equations for the Islamic calendar are shown in the second panel of Table 2. The findings confirm that the volatility of stock returns in the KSE varies with the trading month. Overall, the results suggest that whatever monthly seasonality may be present in the equity returns of Pakistani companies, it is more pronounced in the volatility data than in the mean returns.

According to Table 2, the volatility is especially high in the months of Safar and Shawwal (relative to Zil Hajj); Shawwal being the most volatile. One reason for the month of Shawwal being volatile may be because it falls after Ramadan and includes Eid festivities. During this month, the trading hours of the stock exchange revert back to normal and investors have more time to concentrate on trading as the frequency of prayer service 
declines. This leads to an increase in the trading activity and hence volatility. Therefore, to reduce risk exposure, investors may avoid investing in the months of Shawwal; this month has a higher chance that share returns will be riskier than other months investigated in the current study.

Furthermore, the overall Ramadan coefficient in the variance equation is, on average, negative (-0.0048) and significant for 77.36 percent of the sample firms; Ramadan's volatility is the second lowest (after Jamatul Awwal's -0.0074) compared to any of the other months in the Islamic calendar. The distribution of the coefficients for the month of Ramadan is negatively skewed at -2.23 suggesting that for a sizeable number of firms in the sample the volatility of equity returns in this month tend to be lower than the volatility of equity returns in Zil Hajj. This is consistent with the findings of previous studies that have examined the monthly calendar anomaly in the Pakistani stock market by accounting for both risk and return (Husain, 1998; Mustafa, 2008). The decline in the volatility may be due to the reduced trading hours in the month of Ramadan, or to the fact that investors are devoting more time to religious activities than the market in this month. Or the result may simply be due to the general slow pace of economic activity in the country more generally (Al-Ississ, 2010).

Unlike previous studies, the results in the current investigation also show calendar anomalies in months other than Ramadan and post-Ramadan months. For example, the results suggest that Shawwal is the most volatile month while the month of Jamatul Awwal is the least volatile month followed by the month of Ramadan. This is in contrast to earlier findings which suggested that the month of Ramadan was associated with the lowest volatility (Mustafa, 2008; Seyyed et al., 2005). The low volatility in the month of Jamatul Awwal is a mystery as, unlike other months such as Ramadan, Jamatul Awwal does not contain any holy days. Hence it should not have any impact on the emotions of believers or on the financial markets and is an avenue for future research. 


\subsection{Leverage effect}

The TGARCH model suggests that investors in the KSE appear to respond in an asymmetric fashion to positive and negative news; this finding casts doubt on the appropriateness of previous research which has excluded a leverage effect when modelling the volatility of equity returns (for example, see Husain, 1998). Table 2 shows that the leverage effect is significant for more than a half of the sample firms and the distribution of the leverage effect is asymmetric and negatively skewed. From Table 2, the results indicate that the leverage coefficient is 0.0013. Furthermore, 69.81 percent of firms reported a significant leverage effect. The leverage effect was positive and statistically significant for most companies (57.55 percent significant) suggesting that, on average, bad news induced a higher volatility in the returns than good news. However, for a sizeable minority the opposite pattern was present. Thus, studies need to consider the effect of good and bad news on share prices when examining returns and volatility to eliminate any risk of spurious results.

\subsection{The volatility shift after $9 / 11$}

Lastly, the volatility of the shares listed in the KSE market changed considerably after the attacks on the World Trade Centre in the US on $9 / 11$. The results indicate that 92.45 percent of the sample firms have lower levels of stock return volatility after $9 / 11$. This may be attributable to the stock exchange reforms which were introduced after 9/11. The estimation results show that, on average, the volatility declined by 0.0051 . According to Table 2, a majority of firms (70.75 percent) have a negative coefficient; this finding suggests that for most companies, the volatility of share returns was lower in the post-9/11 period. Such a finding is consistent with the studies of Hameed and Ashraf (2006) and Nguyen and Enomoto (2009). 


\section{Conclusion}

This paper employs a TGARCH model to analyse Islamic monthly calendar anomalies in the share returns of 106 Pakistani firms listed on the KSE. The results show that the calendar effect exists not only in Ramadan, but in other Islamic months as well.

Positive returns are present in some of the Islamic months (Ramadan, Shawwal, Zil Qa'ad, Rabiul Awwal) while negative returns are present in other Islamic months with the lowest returns in Rajab; however, these are not significant for most of the individual firms. By contrast, the calendar anomaly for return volatility is significant. More specifically, while the return volatility in Jamatul Awwal and Ramadan is lower than in other Islamic months, the return volatility in Shawwal is higher than in any other Islamic months. In addition, the KSE market responds in an asymmetric manner to good and bad news; on average, bad news results in a higher volatility of returns than good news. The significance of the estimators in the TGARCH models reflects the fact that in the Pakistani stock market volatility clustering and asymmetric responses to news are present, so risk needs to be adequately modelled. Moreover, we find that return volatility has been significantly reduced in Pakistan after 9/11 casting doubts on the appropriateness of the previous research that has overlooked this effect in their analysis of monthly anomalies in Pakistan.

This finding may have useful implications for trading strategies and investment decisions which investors may seek to implement for monthly prices; investors can time their trading thereby earning abnormal returns. The month that offers the investor the greatest chance to make a risk-adjusted profit is Ramadan while the month that the investor should avoid because of the relatively high chance of making a loss is Rajab. Thus, investors can buy shares in the month of Ramadan and benefit from the typical uplift in prices which usually arise and sell in Rajab. Furthermore, investors may be able to use the monthly seasonality information supplied to avoid (or reduce) risk when investing in the Pakistani stock market; 
Jamatul Awwal seems to be the best month for employing such a strategy, followed by Ramadan; the significant reduction in volatility may offer an attractive opportunity to investors. The month where an investor would face higher risk is Shawwal.

The Islamic calendar differs from its Gregorian counterpart such that the dates (according to the Gregorian calendar) on which Islamic months fall each year keep moving. Any Islamic calendar effects are likely to be caused by factors related to the Islamic religion and inherent cultural influences. Future work is needed in this area to identify whether religious factors affect other stock markets and whether investors should sell in Rajab and buy in Ramadan. Thus, further work on other Muslim countries could be a future avenue for research: a possible investigation could test the results for the current study to see if the results repeat on the stock market indices of other predominantly Muslim countries.

\section{References}

Ahmed, E., \& Rosser, J. B. (1995). Non-linear speculative bubbles in the Pakistani stock market. The Pakistan Development Review, 34(1), 25-41.

Ahmed, S., \& Farooq, O. (2008). The effect of 9/11 on the stock market volatility dynamics: empirical evidence from a front line state. International Research Journal of Finance and Economics, 16, 71-83.

Al-Hajieh, H., Redhead, K., \& Rodgers, T. (2011). Investor sentiment and calendar anomaly effects: A case study of the impact of Ramadan on Islamic Middle Eastern markets. Research in International Business and Finance, 25(3), 345-356.

Ali, S., \& Akbar, M. (2009). Calendar effects in Pakistani stock market. International Review of Business Research Papers, 5(1), 389-404.

Al-Khazali, O. (2014). Revisiting fast profit investor sentiment and stock returns during Ramadan. International Review of Financial Analysis, Forthcoming.

Al-Ississ, M. (2010). The impact of religious experience on financial markets. Working paper. Harvard Kennedy School of Government.

Almudhaf, F. (2012). The Islamic calendar effects: Evidence from twelve stock markets. International Research Journal of Finance and Economics, 87, 185-191. 
Ariel, R. A. (1987). A monthly effect in stock returns. Journal of Financial Economics, $18(1), 161-174$.

Arif, M. (2007). Developing Bond Market in Pakistan, State Bank of Pakistan Research Bulletin, 3(1), 129-157.

Beller, K., Nofsinger, J. R. (1998). On stock return seasonality and conditional heteroskedasticity. The Journal of Financial Research, 21(2), 229-246.

Berndt, E., Hall, B., Hall R., \& Hausman, J. (1974). Estimation and inference in nonlinear structural models. Annals of Economic and Social Measurement, 3(4), 653-665.

Bialkowski, J., Etebari, A., \& Wisniewski, T. (2012). Fast profits: Investor sentiment and stock returns during Ramadan. Journal of Banking and Finance, 36(3), 835-845.

Black, F. (1976). Studies of stock price volatility changes. Proceedings of the 1976 meetings of the business and economics statistics section. American Statistical Association, $177-181$.

Bley, J., \& Saad, M. (2010). Cross-cultural differences in seasonality. International Review of Financial Analysis, 19(4), 306-312.

Bollerslev, T., \& Wooldridge, J. M. (1992). Quasi-maximum likelihood estimation and inference in dynamic models with time-varying covariances. Econometric Reviews, $11,143-172$.

Brooks, R. M., \& Kim, H. (1997). The individual investor and the weekend effect: A reexamination with intraday data. The Quarterly Review of Economics and Finance, $37(3), 725-737$.

Canepa, A., \& Ibnrubbian, A. (2014). Does faith move stock markets? Evidence from Saudi Arabia. The Quarterly Review of Economics and Finance, Forthcoming.

Chan, M., Khanthavit, A., \& Hugh, T. (1996). Seasonality and cultural influences on four Asian stock markets. Asia Pacific Journal of Management, 13, 1-24.

Dbouk, W., Jamali, I., \& Kryzanowski, L. (2013). The January effect for individual corporate bonds. International Review of Financial Analysis, 30, 69-77.

Dyl, E. (1977), Capital gains taxation and year-end stock market behaviour. Journal of Finance 32(1), 165-175.

Engle, R. F. (1982). Autoregressive conditional heteroskedasticity with estimates of the variance of United Kingdom inflation. Econometrica, 50(4), 987-1007.

Fama, E. F., \& Blume, M. E. (1966). Filter rules and stock-market trading. Journal of Business, 39(1), 226-241.

Farid, A., \& Ashraf, J. (1995). Volatility at Karachi stock exchange. The Pakistan Development Review, 34(4), 651-657. 
Gamble, R. Jr. (1993). The January effect and intergenerational transfers. The Quarterly Review of Economics and Finance, 33(3), 295-304.

Gultekin, M. N., \& Gultekin, N. B. (1983). Stock market seasonality - International evidence. Journal of Financial Economics, 12(4), 469-481.

Halari, A. (2015). Investigating Calendar Influence in the Karachi Stock Exchange. International Research Journal of Finance and Economics, 118, 131-145.

Hameed, A., \& Ashraf, H. (2006). Stock market volatility and weak-form efficiency: Evidence from an emerging market. The Pakistan Development Review, 45(4), 10291040.

Harris, L. (1986). A transaction data study of weekly and intradaily patterns in stock returns. Journal of Financial Economics, 16(1), 99-117.

Hepsen, A. (2012). Calendar anomalies and Turkish real estate investment trusts (REITs). International Journal of Economics and Finance, 4(3), 230-236.

Husain, F. (1998). A seasonality in the Pakistani equity market: The Ramadhan effect. The Pakistan Development Review, 37(1), 77-81.

Hussain, F., Hamid, K., Akash, R. S. I., \& Khan, M. I. (2011). Day of the week effect and stock returns: (Evidence from Karachi stock exchange-Pakistan). Far East Journal of Psychology and Business, 3(1), 25-31.

Iqbal, J. (2012). Stock market in Pakistan: An overview. Journal of Emerging Market Finance, 11(1), 61-91.

Jaffe, J. and Westerfield, R. (1985). The weekend effect in common stock market returns: The international evidence. Journal of Finance, 40(2), 433-454.

Jensen, M. C. (1978). Some anomalous evidence regarding market efficiency. Journal of Financial Economics, 6, 95-101.

Kanasro, H. A., Rohra, C. L., \& Junejo, M. A. (2009). Measurement of stock market volatility through $\mathrm{ARCH}$ and GARCH Models: A case study of Karachi stock exchange. Australian Journal of Basic and Applied Sciences, 3(4), 3123-3127.

Mirza, K. A. (1993). Pakistan: A small market with potential. In: The world's emerging stock market - structure, development, regulations and opportunities: by Park, K.K. H., Van Agtmael and A.W., Probus Publishing Company, Chicago, 197-221.

Mustafa, K. (2008). The Islamic calendar effect in Karachi stock market. Proceedings of the 8th International Business Research Conference, Dubai, UAE.

Mustafa, K., \& Nishat, M. (2007). Testing for market efficiency in emerging markets: A case study of the Karachi stock market. The Lahore Journal of Economics, 12(1), 119-140. 
Nawazish, M., \& Sara, S. M. (2012). Time varying stock market volatility: The case of an emerging market. Research Journal of Recent Sciences, 1(11), 41-46.

Nguyen, A. P., \& Enomoto, C. E. (2009). Acts of terrorism and their impacts on stock index returns and volatility: The cases of the Karachi and Tehran stock exchanges. International Business and Economics Research Journal, 8(12), 75-86.

Nishat, M., \& Mustafa, K. (2002). Anomalies in Karachi stock market: Day of the week effect. The Bangladesh Development Studies, 28(3), 55-64.

Oguzsoy, C. B., \& Guven, S. (2004) Holy days effect on Istanbul stock exchange. Journal of Emerging Market Finance, 3(1), 63-75.

Rafique, M., \& Shah, Z. A. (2012). Investigating January effect in Karachi stock exchange. International Research Journal of Finance and Economics, 92, 87-93.

Roll, R. (1983). Vast ist das? The turn of the year effect and the return premium of small firms. Journal of Portfolio Management, 9(2), 18-28.

Seyyed, F., Abraham, A., \& Al-Hajji, M. (2005). Seasonality in stock returns and volatility: The Ramadan effect. Research in International Business and Finance, 19(3), 374383.

Suleman, M. T. (2012). Stock market reaction to terrorist attacks: Empirical evidence from a front line state. Australian Accounting Business and Finance Journal, 6(1), 97-110.

Ullah, S., Ullah, O., \& Usman, A. (2010). Market efficiency anomalies: A study of day of the week effect in Pakistani stock market. Interdisciplinary Journal of Contemporary Research in Business, 2(6), 272-281.

Weber, M. (1930). The Protestant Ethic and the Spirit of Capitalism. New York: Scribner's.

Zafar, N., Urooj, S. F., \& Farooq, S. U. (2010). Karachi stock exchange: Testing month of the year effect. European Journal of Economics, Finance and Administrative Sciences, $24,20-28$. 
Table 1 Summary Statistics for the Average Returns over the 17-year Period

\begin{tabular}{|l|c|c|c|c|c|c|c|}
\hline Month & MEAN & SD & MIN & MAX & SKEW & KURT & JB \\
\hline Muharram & -0.00023 & 0.0102 & -0.045 & 0.027 & -0.86 & 5.39 & $127.26^{*}$ \\
\hline Safar & -0.00031 & 0.0136 & -0.052 & 0.052 & -0.38 & 5.28 & $81.10^{*}$ \\
\hline Rabiul Awwal & 0.00060 & 0.0124 & -0.060 & 0.067 & 0.06 & 7.07 & $235.11^{*}$ \\
\hline Rabiul Thani & -0.00019 & 0.0103 & -0.031 & 0.039 & 0.25 & 4.39 & $30.76^{*}$ \\
\hline Jamatul Awwal & -0.00033 & 0.0111 & -0.040 & 0.045 & -0.17 & 5.45 & $90.05^{*}$ \\
\hline Jamatul Thani & -0.00026 & 0.0119 & -0.059 & 0.061 & 0.15 & 8.35 & $411.09^{*}$ \\
\hline Rajab & -0.00058 & 0.0114 & -0.051 & 0.032 & -0.73 & 5.37 & $112.33^{*}$ \\
\hline Shaban & -0.00053 & 0.0105 & -0.037 & 0.039 & -0.35 & 4.62 & $46.19^{*}$ \\
\hline Ramadan & 0.00175 & 0.0098 & -0.047 & 0.045 & -0.15 & 6.00 & $124.11^{*}$ \\
\hline Shawwal & 0.00116 & 0.0119 & -0.046 & 0.060 & 0.25 & 5.84 & $106.38^{*}$ \\
\hline Zil Qa'ad & 0.00115 & 0.0109 & -0.041 & 0.045 & -0.13 & 4.55 & $36.01^{*}$ \\
\hline Zil Hajj & -0.00048 & 0.0113 & -0.047 & 0.046 & -0.89 & 6.23 & $174.04^{*}$ \\
\hline
\end{tabular}

Note: This table shows the descriptive data for the average daily returns across 106 sample firms according to the Islamic calendar. The mean is the equally-weighted average of all daily observations over the 17-year period. SD, Min and Max donate the standard deviation, the minimum daily return and the maximum daily return, respectively. Skew refers to the Kendall-Stuart measure of skeweness while Kurt is the Kendall-Stuart measure of kurtosis. JB refers to the Jarque-Bera test for normality. An * indicates significance at the 0.05 significance level. 
Table 2: TGARCH Summary Table: Islamic Calendar - All Sample Firms

\begin{tabular}{|c|c|c|c|c|c|c|c|c|}
\hline & Avg & $\% \mathrm{Sig}$ & $\% \mathrm{Neg}$ & MIN & MAX & SD & SKEW & KURT \\
\hline \multicolumn{9}{|l|}{ Mean Equation } \\
\hline Muharram & -0.0027 & 1.89 & 48.11 & -0.8237 & 1.0758 & 0.28 & 0.04 & $1.95^{*}$ \\
\hline Safar & -0.0017 & 2.83 & 44.34 & -0.7407 & 0.8044 & 0.25 & -0.25 & $1.84^{*}$ \\
\hline Rabiul Awwal & 0.0378 & 1.89 & 42.45 & -0.8630 & 1.8034 & 0.27 & $2.31^{*}$ & $18.20^{*}$ \\
\hline Rabiul Thani & -0.0504 & 4.72 & 53.77 & -0.8120 & 1.2351 & 0.29 & 0.30 & $3.50^{*}$ \\
\hline Jamatul Awwal & -0.0373 & 0.94 & 59.43 & -0.8608 & 1.3810 & 0.24 & $1.57^{*}$ & $10.69^{*}$ \\
\hline Jamatul Thani & -0.0500 & 2.83 & 49.06 & -3.4655 & 0.8219 & 0.44 & $-4.67 *$ & $34.12 *$ \\
\hline Rajab & -0.0941 & 2.83 & 65.09 & -1.2908 & 1.2531 & 0.29 & 0.14 & $5.48^{*}$ \\
\hline Shaban & -0.0049 & 2.83 & 50.94 & -0.8570 & 0.8699 & 0.23 & 0.11 & $2.94 *$ \\
\hline Ramadan & 0.1250 & 5.66 & 24.53 & -0.9953 & 0.9133 & 0.26 & $-1.06^{*}$ & $5.23 *$ \\
\hline Shawwal & 0.0461 & 4.72 & 40.57 & -1.3209 & 2.0501 & 0.36 & $0.71 *$ & $10.62 *$ \\
\hline Zil Qa'ad & 0.0899 & 1.89 & 35.85 & -0.9317 & 1.7113 & 0.29 & $1.19 *$ & $8.90 *$ \\
\hline$\mu$ & -0.0142 & 0.00 & 44.33 & -1.2861 & 0.7469 & 0.20 & $-1.96^{*}$ & $15.06^{*}$ \\
\hline \multicolumn{9}{|l|}{ Variance } \\
\hline \multicolumn{9}{|l|}{ Equation } \\
\hline Muharram & -0.0024 & 72.64 & 53.77 & -0.1251 & 0.1196 & 0.03 & -0.29 & $5.40 *$ \\
\hline Safar & 0.0003 & 79.25 & 48.11 & -0.0933 & 0.2084 & 0.03 & $3.37^{*}$ & $26.70^{*}$ \\
\hline Rabiul Awwal & -0.0034 & 74.53 & 56.60 & -0.1230 & 0.0832 & 0.03 & $-0.80^{*}$ & $4.50^{*}$ \\
\hline Rabiul Thani & -0.0042 & 67.92 & 60.38 & -0.1573 & 0.1690 & 0.03 & $0.95^{*}$ & $13.31 *$ \\
\hline Jamatul Awwal & -0.0074 & 71.70 & 58.49 & -0.1214 & 0.0423 & 0.02 & $-2.72 *$ & $10.25^{*}$ \\
\hline Jamatul Thani & -0.0039 & 75.47 & 51.89 & -0.1929 & 0.1579 & 0.03 & $-0.96^{*}$ & $13.81^{*}$ \\
\hline Rajab & -0.0035 & 75.47 & 50.94 & -0.1247 & 0.0648 & 0.02 & $-1.88 *$ & $8.30^{*}$ \\
\hline Shaban & -0.0029 & 72.64 & 51.89 & -0.1461 & 0.1359 & 0.03 & $-1.08 *$ & $12.23 *$ \\
\hline Ramadan & -0.0048 & 77.36 & 39.62 & -0.1333 & 0.0651 & 0.03 & $-2.23 *$ & $8.25^{*}$ \\
\hline Shawwal & 0.0006 & 65.09 & 52.83 & -0.1637 & 0.1368 & 0.03 & -0.20 & $8.78^{*}$ \\
\hline Zil Qa'ad & -0.0043 & 75.47 & 53.77 & -0.1307 & 0.0822 & 0.03 & $-1.56^{*}$ & $7.83 *$ \\
\hline$\theta$ & 0.0257 & 96.23 & 6.60 & -0.0314 & 0.2031 & 0.04 & $2.55^{*}$ & $7.31 *$ \\
\hline $\mathrm{ARCH}$ & 0.1252 & 100.00 & 0.94 & -0.0164 & 0.4405 & 0.07 & $1.12 *$ & $4.08 *$ \\
\hline GARCH & 0.7532 & 98.11 & 0.00 & 0.0293 & 0.9778 & 0.17 & $-1.75^{*}$ & $4.22 *$ \\
\hline Leverage & 0.0013 & 69.81 & 42.45 & -0.3646 & 0.1645 & 0.07 & $-1.39 *$ & $5.89^{*}$ \\
\hline $9 / 11$ & -0.0051 & 92.45 & 70.75 & -0.1183 & 0.1083 & 0.02 & $-1.07^{*}$ & $11.38^{*}$ \\
\hline
\end{tabular}

Note: This summary table shows the average coeffcients for the 106 sample firms. $\mu$ and $\theta$ represents the effect of Zil Hajj. Mean and Variance of the coefficients of Muharram - Zil Qa'ad. 9/11 is a dummy variable representing the observations in the period after $9 / 11 . \%$ Sig refers to the percentage of statistical significant of sample firms at 1 and 5 percent level while $\% \mathrm{Neg}$ implies the percentage of negative values for all the sample firms across different months. Min, Max and SD donate the minimum daily return, the maximum daily return and the standard deviation, respectively. Skew refers to the Kendall-Stuart measure of skeweness while Kurt is the Kendall-Stuart measure of kurtosis. * notes the rejection of the null hypothesis of the normality at the 0.05 significance level. 
Figure 1 Mean Returns and Standard Deviation (Post 9/11 vs Pre 9/11).

$$
\text { Post 9/11 - Pre 9/11 }
$$

0.06

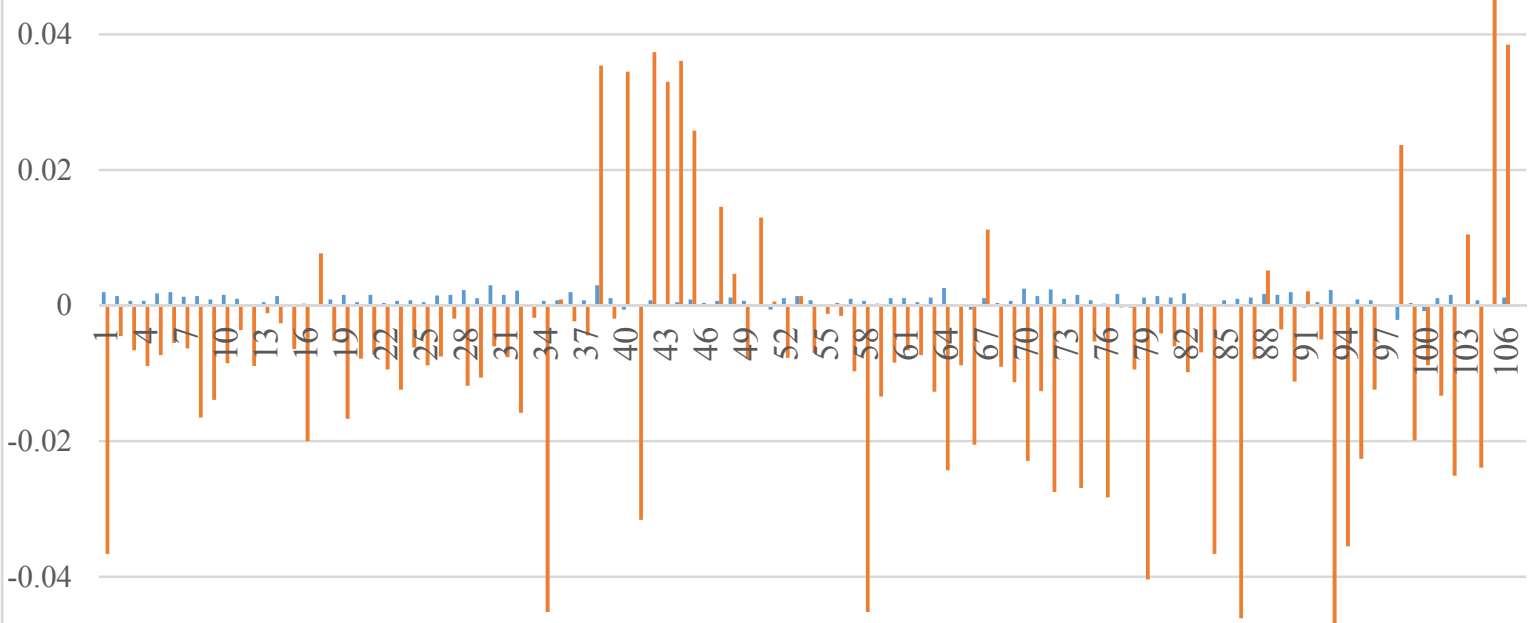

$-0.06$

$$
\square \text { Mean } \square \text { SD }
$$

Note: This figure presents the difference (post 9/11 - pre 9/11) in mean (MEAN) and the standard deviation (SD) for all the 106 sample companies. 
Figure 2 Stock Returns for ULV, PSM, PCT and MBK during 1995 to 2011

ULV

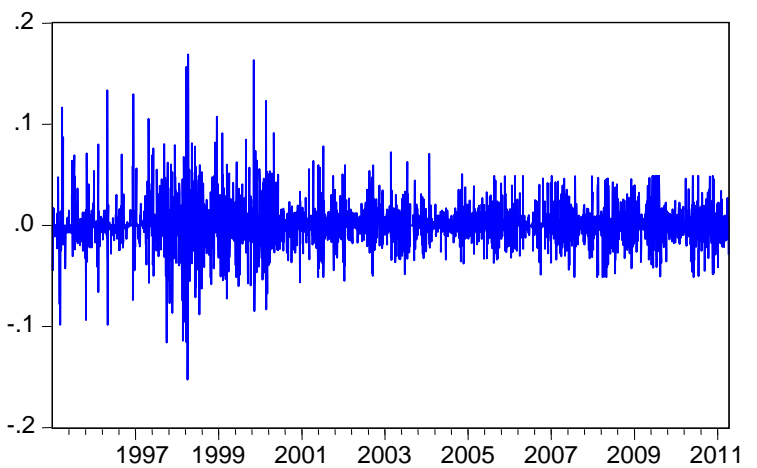

PCT

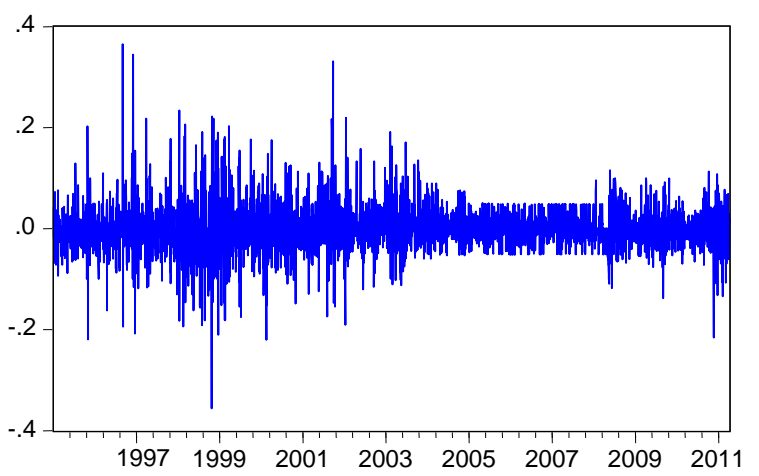

PSM

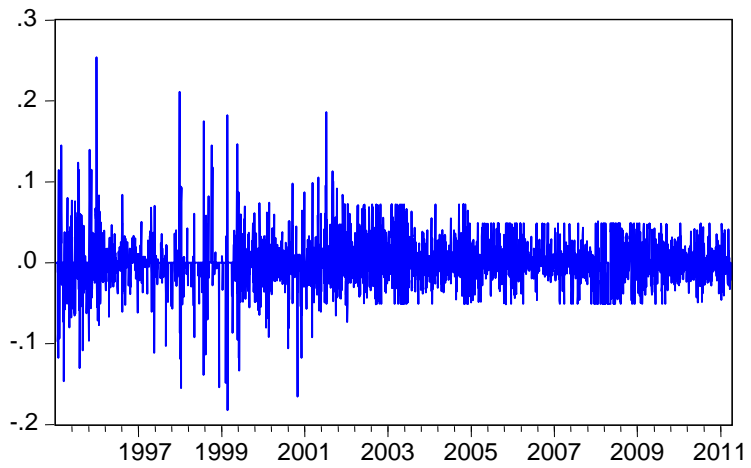

MBK

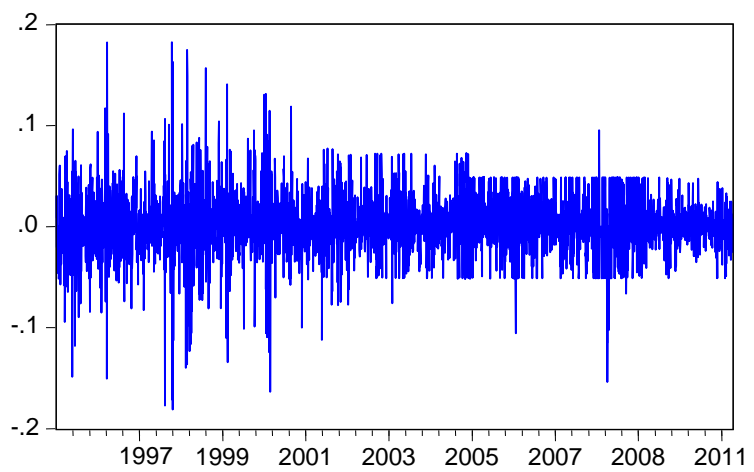

Note: The firms shown in the figure are Unilever Pakistan (ULV), Pakistan Suzuki Motor (PSM), Pioneer Cement (PCT) and MCB Bank (MBK). 


\section{Appendix 1 Information about the Sample Companies}

\begin{tabular}{|c|c|c|c|c|c|c|}
\hline No. & Company names & Code & Mkt Cap & VO & DY & $\mathbf{P} / \mathbf{E}$ \\
\hline 1 & AGRIAUTO INDUSTRIES & AGR & 1656.00 & 2604.10 & 8.70 & 3.80 \\
\hline 2 & SERVICE INDUSTRIES & SER & 2345.49 & 2628.00 & 3.21 & 7.10 \\
\hline 3 & ATLAS HONDA & ATH & 8789.02 & 947.00 & 4.63 & 12.30 \\
\hline 4 & GENERAL TYRE \& RUBBER & GTR & 1249.82 & 6342.60 & 11.96 & 4.80 \\
\hline 5 & INDUS MOTOR COMPANY & IMO & 16115.37 & 9499.90 & 7.32 & 5.90 \\
\hline 6 & PAK SUZUKI MOTOR & PSM & 4858.15 & 10966.70 & 0.85 & 23.00 \\
\hline 7 & ASKARI BANK & $\mathrm{ACB}$ & 7091.39 & 158595.00 & 6.71 & 6.80 \\
\hline 8 & BANK OF PUNJAB & BKP & 2860.79 & 506684.10 & 0.00 & $\mathrm{~N} / \mathrm{A}$ \\
\hline 9 & HABIB METROPOLITAN BANK & MET & 17697.87 & 20278.40 & 0.00 & 5.20 \\
\hline 10 & MCB BANK & MBK & 112557.40 & 260888.10 & 8.71 & 6.70 \\
\hline 11 & NIB BANK & NAT & 17823.92 & 460454.20 & 0.00 & 5.50 \\
\hline 12 & SAMBA BANK & $\mathrm{CCB}$ & 2078.54 & 37897.80 & 0.00 & 7.30 \\
\hline 13 & SONERI BANK & SON & 3521.38 & 35754.10 & 30.90 & 22.10 \\
\hline 14 & AL-NOOR MODARBA MAN & ALN & 88.20 & 798.60 & 19.05 & 8.00 \\
\hline 15 & FIRST TRISTAR MOD & ART & 23.28 & 445.70 & 0.00 & 2.90 \\
\hline 16 & PICIC GROWTH FUND & ICP & 3532.41 & 60751.40 & 30.50 & 6.40 \\
\hline 17 & MODARBA AL-MAL & MAL & 14.37 & 1397.10 & 0.00 & N/A \\
\hline 18 & STANDARD CHT.MODARABA & GOP & 469.72 & 2663.90 & 16.67 & 5.90 \\
\hline 19 & TRUST MODARABA & TMS & 58.11 & 733.20 & 12.82 & 2.50 \\
\hline 20 & UNICAP MODARBA LTD & UMC & 4.09 & 118.50 & 0.00 & N/A \\
\hline 21 & ENGLISH LEASING & ENL & 5.20 & 158.80 & 0.00 & N/A \\
\hline 22 & INVEST CAPITAL INV.BANK & ASB & 56.97 & 12796.00 & 0.00 & 0.10 \\
\hline 23 & ORIX LEASING PAK. & ORI & 521.04 & 5744.80 & 15.75 & 3.60 \\
\hline 24 & SECURITY INVESTMENT BANK & SEC & 64.29 & 1636.30 & 0.00 & 6.60 \\
\hline 25 & TRUST INVESTMENT BANK & TRU & 40.99 & 1601.10 & 0.00 & N/A \\
\hline 26 & ADAMJEE INSURANCE & ADI & 5753.50 & 149533.40 & 5.38 & 11.10 \\
\hline 27 & CENTRAL INSURANCE & CEI & 1955.03 & 799.30 & 3.43 & 2.80 \\
\hline 28 & EFU GENERAL INSURANCE & ETU & 4768.75 & 9469.90 & 3.28 & N/A \\
\hline 29 & JUBILLE INSURANCE & JIN & 5270.87 & 725.00 & 3.00 & 9.40 \\
\hline 30 & MURREE BREWERY COMPANY & MRB & 1210.19 & 2467.50 & 7.16 & 3.80 \\
\hline 31 & DEWAN SUGAR & DSM & 73.02 & 8401.00 & 0.00 & N/A \\
\hline 32 & HABIB ADM LIMITED & HAB & 547.20 & 1461.90 & 14.62 & 4.70 \\
\hline 33 & HABIB SUGAR & HSM & 3286.50 & 12387.60 & 11.41 & 6.10 \\
\hline 34 & MIRPURKHAS SUGAR & MIR & 342.64 & 180.50 & 2.46 & 4.10 \\
\hline 35 & NESTLE PAKISTAN & NPK & 163127.40 & 318.60 & 1.53 & 39.70 \\
\hline 36 & NOON SUGAR MILLS & NON & 220.18 & 1265.50 & 0.00 & N/A \\
\hline 37 & SHAKARGANJ MILLS & SHK & 335.10 & 2968.90 & 20.75 & $\mathrm{~N} / \mathrm{A}$ \\
\hline 38 & UNILEVER PAKISTAN & ULV & 73990.94 & 120.20 & 4.71 & 22.60 \\
\hline 39 & PAKISTAN TOBACCO & PTC & 14179.90 & 4945.00 & 15.77 & 15.30 \\
\hline 40 & PHILIP MORRIS PAKISTAN & LAK & 8559.66 & 333.90 & 1.80 & 14.90 \\
\hline 41 & AL-ABBAS CEMENT & $\mathrm{AAC}$ & 914.22 & 13474.40 & 0.00 & $\mathrm{~N} / \mathrm{A}$ \\
\hline 42 & CHEARAT CEMENT COMPANY & CTC & 689.13 & 5705.80 & 0.00 & $\mathrm{~N} / \mathrm{A}$ \\
\hline 43 & DADABHOY CEMENT & DAD & 138.51 & 4978.30 & 0.00 & 20.10 \\
\hline 44 & DANDOT CEMENT & DAN & 110.01 & 1029.80 & 0.00 & $\mathrm{~N} / \mathrm{A}$ \\
\hline 45 & DEWAN CEMENT & PLC & 486.39 & 79764.90 & 0.00 & $\mathrm{~N} / \mathrm{A}$ \\
\hline 46 & DG KHAN CEMENT COMPANY & DEG & 8337.40 & 826903.20 & 0.00 & 35.80 \\
\hline 47 & FECTO CEMENT & FEC & 195.62 & 1400.40 & 0.00 & $\mathrm{~N} / \mathrm{A}$ \\
\hline 48 & GHARIBWAL CEMENT & GWC & 2233.53 & 3287.10 & 0.00 & N/A \\
\hline 49 & MAPLE LEAF CMT.FACTORY & MLC & 974.42 & 58326.00 & 0.00 & N/A \\
\hline 50 & PIONEER CEMENT & PCT & 749.59 & 28659.00 & 0.00 & N/A \\
\hline 51 & SHABIR TILES & SHA & 1161.26 & 516.40 & 0.00 & N/A \\
\hline 52 & PACKAGES & PAC & 6979.88 & 16996.90 & 3.93 & N/A \\
\hline 53 & SIEMENS ENGINEERING & SME & 8715.05 & 222.60 & 8.52 & 8.70 \\
\hline 54 & PAK ELEKTRON & PET & 425.32 & 54255.10 & 0.00 & 2.90 \\
\hline 55 & AL-GHAZI TRACTORS & AGT & 8279.86 & 1675.50 & 11.67 & 4.30 \\
\hline
\end{tabular}




\begin{tabular}{|c|c|c|c|c|c|c|}
\hline 56 & BOLAN CASTINGS & $\mathrm{BOC}$ & 297.24 & 686.20 & 5.26 & 3.60 \\
\hline 57 & DEWAN AUTV.ENGR. & ALT & 16.05 & 7632.70 & 0.00 & $\mathrm{~N} / \mathrm{A}$ \\
\hline 58 & HINOPAK MOTORS & HPM & 868.66 & 152.30 & 0.00 & $\mathrm{~N} / \mathrm{A}$ \\
\hline 59 & MILLAT TRACTORS & MTT & 13368.65 & 18104.90 & 13.01 & 5.90 \\
\hline 60 & PAKISTAN ENGINEERING & PEN & 204.79 & 73.20 & 13.89 & 1.70 \\
\hline 61 & CRESCENT STEEL & CSA & 1024.75 & 12020.60 & 19.28 & 2.50 \\
\hline 62 & HUFFAZ SEAMLESS PIPE & HUF & 448.87 & 3465.10 & 18.54 & 3.50 \\
\hline 63 & INTERNATIONAL INDS. & INI & 4557.11 & 18755.70 & 13.15 & 16.20 \\
\hline 64 & PAKISTAN NAT.SHIP. & PNS & 1678.53 & 2765.30 & 7.87 & 2.40 \\
\hline 65 & HUB POWER COMPANY & HUB & 39574.69 & 407066.00 & 16.08 & 7.10 \\
\hline 66 & KARACHI ELECTRIC SUPPLY & KIE & 36619.39 & 247777.80 & 0.00 & $\mathrm{~N} / \mathrm{A}$ \\
\hline 67 & PAKISTAN CABLES & PNC & 910.80 & 1078.70 & 6.25 & 20.00 \\
\hline 68 & PAKISTAN TELECM. & TLM & 39211.84 & 510110.60 & 16.84 & 5.70 \\
\hline 69 & SUI NORTHERN GAS & SNG & 9057.76 & 95455.80 & 6.06 & 3.50 \\
\hline 70 & SUI SOUTHERN GAS & SUI & 16992.87 & 148805.60 & 12.34 & 3.60 \\
\hline 71 & ATTOCK REFINERY & ATR & 9181.79 & 329743.70 & 1.86 & 72.60 \\
\hline 72 & NATIONAL REFINERY & NAR & 19407.08 & 41126.70 & 10.30 & 5.90 \\
\hline 73 & PAKISTAN OILFIELDS & POF & 81951.25 & 397542.40 & 10.10 & 11.00 \\
\hline 74 & PAKISTAN REFINERY & PRE & 947.94 & 16113.50 & 2.22 & $\mathrm{~N} / \mathrm{A}$ \\
\hline 75 & PAKISTAN STATE OIL & PSO & 38970.80 & 195845.90 & 4.40 & 4.30 \\
\hline 76 & SHELL PAKISTAN & PBS & 13031.88 & 8727.50 & 6.31 & 8.10 \\
\hline 77 & SECURITY PAPER & SEP & 1456.71 & 2100.40 & 14.12 & 4.60 \\
\hline 78 & CENTURY PAPER & $\mathrm{CPB}$ & 918.88 & 22576.30 & 0.00 & 21.70 \\
\hline 79 & PAKISTAN INTL.AIRLINES & PAL & 5076.18 & 63468.90 & 0.00 & $\mathrm{~N} / \mathrm{A}$ \\
\hline 80 & BATA PAKISTAN & BAP & 6187.10 & 368.40 & 1.47 & 7.10 \\
\hline 81 & CRESCENT TEXTILE MILLS & CTX & 405.00 & 530.50 & 0.00 & 1.20 \\
\hline 82 & FAZAL TEXTILE MILLS & FZM & 1525.84 & 470.00 & 2.43 & 4.30 \\
\hline 83 & GADOON TEXTILE & GAT & 960.94 & 2503.70 & 24.39 & 1.20 \\
\hline 84 & GULISTAN SPNG.MILLS & GSM & 60.03 & 1446.10 & 24.39 & 0.90 \\
\hline 85 & KOHINOOR MILLS & KWG & 81.97 & 457.70 & 0.00 & $\mathrm{~N} / \mathrm{A}$ \\
\hline 86 & KOHINOOR TEX.MILLS & KNR & 829.88 & 12324.70 & 0.00 & 3.00 \\
\hline 87 & NISHAT (CHUNIAN) & NHT & 2894.93 & 499244.70 & 11.20 & 3.10 \\
\hline 88 & NISHAT MILLS & NMI & 14222.20 & 751626.60 & 8.16 & 4.90 \\
\hline 89 & PAKISTAN SYNTHETICS & PSC & 1007.04 & 17509.40 & 11.13 & 19.40 \\
\hline 90 & SAIF TEXTILE MILLS & STM & 131.80 & 3282.50 & 40.08 & 1.70 \\
\hline 91 & SAPPHIRE FIBRES & SPP & 2008.32 & 40.70 & 4.90 & 2.80 \\
\hline 92 & TAJ TEXTILE MILLS & TAJ & 8.36 & 356.00 & 0.00 & $\mathrm{~N} / \mathrm{A}$ \\
\hline 93 & TRI-STAR POLYESTER & TRP & 32.49 & 387.10 & 0.00 & $\mathrm{~N} / \mathrm{A}$ \\
\hline 94 & LINDE PAKISTAN & LDP & 2528.91 & 1905.90 & 6.44 & 10.40 \\
\hline 95 & DAWOOD HRC.CHEMS.CORP & DDH & 20401.75 & 25709.50 & 1.77 & 1.60 \\
\hline 96 & DEWAN SALMAN FIBRE & DES & 443.25 & 359031.10 & 0.00 & $\mathrm{~N} / \mathrm{A}$ \\
\hline 97 & ENGRO & ERO & 36457.44 & 566819.90 & 6.11 & 21.80 \\
\hline 98 & FAUJI FERTILIZER & FAU & 126833.60 & 487808.30 & 11.74 & 11.50 \\
\hline 99 & GATRON INDUSTRIES & GAI & 2650.60 & 80.10 & 7.24 & 6.40 \\
\hline 100 & ICI PAKISTAN & ICI & 16693.75 & 93353.10 & 12.89 & 6.90 \\
\hline 101 & SITARA CHEMICAL & SIT & 1547.20 & 1136.50 & 8.66 & 3.30 \\
\hline 102 & ABBOTT LABS.(PAK.) & $\mathrm{ABB}$ & 9769.47 & 1770.40 & 4.58 & 9.00 \\
\hline 103 & GLAXOSMITHKLINE PAK. & GLT & 16050.17 & 6680.50 & 5.19 & 13.20 \\
\hline 104 & SANOFI AVENTIS PAKISTAN & HPN & 1396.66 & 313.70 & 6.91 & 6.20 \\
\hline 105 & WYETH PAKISTAN & WYP & 1165.65 & 12.80 & 1.22 & 44.10 \\
\hline 106 & SEARLE PAKISTAN & SEA & 1518.05 & 11773.30 & 3.03 & 4.10 \\
\hline
\end{tabular}

Note: This table provides details about sample companies; in particular, this table shows the Sector, Code, Market Capitalisation in Rs. Million (Mkt Cap), Volume Traded expressed in Rs. thousands (VO), Dividend Yield (DY) and the Price-Earnings ratio (P/E) for all the 106 sample companies at the end of December 2011. Where the $\mathrm{P} / \mathrm{E}$ ratio was negative, it was replaced by ' $\mathrm{N} / \mathrm{A}$ ' as negative $\mathrm{P} / \mathrm{E}$ ratio is not relevant for this study. The data has been extracted from Datastream and cross-checked from the official website of the KSE. 